Article

\title{
Effect of Corn Residue Biochar on the Hydraulic Properties of Sandy Loam Soil
}

\author{
Avanthi Deshani Igalavithana ${ }^{1, \dagger}$, Yong Sik Ok ${ }^{1, \dagger}$, Nabeel Khan Niazi ${ }^{2,3}$, Muhammad Rizwan ${ }^{4}$, \\ Mohammad I. Al-Wabel ${ }^{5}$, Adel R. A. Usman ${ }^{5}$, Deok Hyun Moon ${ }^{6}$ and Sang Soo Lee ${ }^{1, *}$ \\ 1 Korea Biochar Research Center, School of Natural Resources and Environmental Science, \\ Kangwon National University, Chuncheon 24341, Korea; adigalavithana@gmail.com (A.D.I.); \\ soilok@kangwon.ac.kr (Y.S.O.) \\ 2 Institute of Soil and Environmental Sciences, University of Agriculture Faisalabad, \\ Faisalabad 38040, Pakistan; nabeelkniazi@gmail.com \\ 3 Southern Cross GeoScience, Southern Cross University, Lismore, NSW 2480, Australia \\ 4 Department of Environmental Sciences and Engineering, Government College University, \\ Faisalabad 38000, Pakistan; mrazi1532@yahoo.com \\ 5 Department of Soil Sciences, Saudi Biochar Research Group, King Saud University, \\ P.O. Box 2460, Riyadh 11451, Saudi Arabia; malwabel@ksu.edu.sa (M.I.A.-W.); \\ adosman@ksu.edu.sa (A.R.A.U.) \\ 6 Department of Environmental Engineering, Chosun University, Gwangju 61452, Korea; \\ dmoon10@hotmail.com \\ * Correspondence: sslee97@kangwon.ac.kr; Tel.: +82-33-250-6443 \\ + These authors contributed equally to this work.
}

Academic Editor: Marc A. Rosen

Received: 26 November 2016; Accepted: 4 February 2017; Published: 14 February 2017

\begin{abstract}
Biochar has an ability to alter the biological, chemical, and physical properties of soil due to its physicochemical properties such as surface area, porosity, nutrient retention ability, available nutrient contents, aromaticity, etc. The present study was designed to evaluate the impact of physical properties and application rate of biochar on the hydraulic properties of a sandy loam soil in the short term. Biochar was produced at $500{ }^{\circ} \mathrm{C}$ from dried corn residue (BC500). The BC500 was incorporated at the rates of $0,2.5 \%, 5.0 \%, 7.5 \%$, and $10 \%\left(\mathrm{w} \cdot \mathrm{w}^{-1}\right)$ into the sandy loam soil and filled up to a height of $4 \mathrm{~cm}$, in cores having $5 \mathrm{~cm}$ diameter and height. Each treatment was performed in triplicate and equilibrated for 30 days. Then saturated hydraulic conductivity ( $\mathrm{K}_{\text {sat }}$ ), water holding capacity (WHC), and bulk density were determined in each sample after four days of saturation at room temperature in a water bath. The BC500 particle size distribution, pores, and surface functional groups were assessed. The $\mathrm{K}_{\text {sat }}$ exhibited a highly significant exponential reduction from $0 \%$ to $7.5 \%$ of $\mathrm{BC} 500$ application and approached an asymptote at 10\% BC500. Bulk density showed a significant negative correlation to biochar application rate. The WHC and BC500 application rate illustrated a strong positive relationship. Biochar surface was free from hydrophobic functional groups. The addition of BC500 has a positive influence on soil hydraulic properties, primarily due to the increased soil porosity. The BC500 is composed of a microporous structure and hydrophilic surface that retain water in sandy textured soils. The application of BC500 would be a wise investment to maximize the water use efficiency in soils for agricultural production.
\end{abstract}

Keywords: black carbon; soil amendment; charcoal; soil physics; soil porosity

\section{Introduction}

Soil hydraulic properties are mainly affected by soil texture and structure, which fundamentally govern the soil porosity [1]. Soil porosity is highly dynamic against various natural/anthropogenic 
alterations [2]. For instance, conventional tillage, a common agricultural practice, may destroy or disturb the soil aggregate/structure and pore continuity, thereby threatening soil-aggregate-based porosity [3-5]. Soil porosity is also influenced by the activities of both plant roots and soil organisms [6].

In general, coarse-textured soils are composed of poor structure, low porosity around $0.30-0.35[7,8]$, and a high amount of macropores [2,9]. Hence, the hydraulic properties of coarse-textured soil are a challenge in soil science [10,11].

Many attempts have been made to alter soil porosity artificially, especially to enhance the hydraulic properties or water retention of soils [12]. One of the most effective methods to enhance these properties is adding fine soil particles like clay [13]. The application of organic matter such as manure and compost may also be valuable depending on the land-use purpose [6]. On the other hand, soil compaction, which increases the bulk density and porosity in coarse-textured soil, may be suitable for construction purposes [14,15]. However, coarse-textured soils are more resistant to soil compaction than fine-textured ones [6].

Biochar is an organic material that has gained attention as a sustainable soil conditioner [16-21]. Biochar is known to have large surface area, a porous structure, and a negatively charged surface with large charge density $[17,22,23]$. Biochar positively affects the chemical and biological properties of soils including $\mathrm{pH}$, cation exchange capacity (CEC), nutrient availability, plant growth promoting microbial colonization, etc. [21,24]. In addition, biochar reduces the bioavailability of organic and inorganic contaminants, thereby decreasing their uptake by plants [17,25-27]. Biochar incorporation has been known to improve soil physical properties. For example, the application of biochar increases soil water holding capacity (WHC) and plant available water content [28-31], and improves both un/saturated soil hydraulic conductivities [32-34]. It has been reported to slow down and speed up downward water movement in sandy soils and clayey soils, respectively $[35,36]$. Hence, biochar can be used to increase water retention in sandy soils, and to reduce water stagnation in clayey soils.

The porous structure of biochar is created during the biomass pyrolysis due to the removal of volatile compounds from the pore spaces, and biochar soil application could improve soil physical properties due to its porous structure [17,37]. The type of biomass and pyrolysis conditions (i.e., temperature, heating rate, holding time, etc.) affect the development of the porous structure and the size of the pores in biochar [38]. Biochar porosity can be classified as micropores: $<2 \mathrm{~nm}$, mesopores: 2-50 $\mathrm{nm}$, and macropores: $>50 \mathrm{~nm}$ based on the IUPAC classifications of porous materials [39]. Since all pore sizes are limited to the nano-scale, Downie et al. [40] described biochar porocity as "biochar nano-porosity". Biochar pores would have a better capability to enhance the soil porosity in a coarse-textured soil while enhancing the soil water retention [41]. Moreover, biochar-amended soils have an ability to retain and maintain high water content during drought periods [8]. However, the addition of biochar does not always show positive behavior in a coarse-textured soil. Many reports have documented the positive impacts of biochar on soil physical properties [42-47], but others do not [48-50]. Thus, there is a requirement for appraising the role of specific biochar/s on the soil physical properties in desired soil texture/s.

This study was conducted to evaluate the hydraulic properties of a sandy loam soil treated with corn residue biochar produced at $500{ }^{\circ} \mathrm{C}$ (BC500). We hypothesized that the addition of BC500 may improve the soil hydraulic properties along with reducing bulk density and enhancing porosity.

\section{Methodology}

\subsection{Biochar Production and Characterization}

The corn crop residue was collected from a field in Chuncheon, Korea. Those were air dried and ground into small particles ( 2 $\mathrm{mm}$ ). Biochar was produced by pyrolyzing the biomass in a muffle furnace (N 11/H, Nabertherm GimbH, Lilienthal, Germany) under a limited oxygen condition in covered porcelain crucibles. The peak temperature of pryrolysis of $500{ }^{\circ} \mathrm{C}$ was obtained at a heating rate of $7^{\circ} \mathrm{C} \cdot \mathrm{min}^{-1}$. Complete carbonization was accomplished by holding the peak temperature for $2 \mathrm{~h}$. 
Produced biochar was named as BC500. The BC500 was sieved through a 2-mm sieve. The particle size distribution analysis of BC500 was done using a particle size analyzer (MASTERSIZER 2000, Malvern Instruments Ltd., Malvern, UK) and the pore arrangement on the particle surface was observed with a scanning electron microscope (SEM, HITACHI S 4300). Pore size distribution of biochar particles was further studied using Brunauer-Emmett-Teller (BET, Gemini VII Version 3.03, Micromeritics Instrument Corp., Norcross, GA, USA). The surface functional groups of BC500 were characterized by Fourier transformed infrared (FTIR) spectroscopic analysis (Excalibur 3000MX; Bio-Rad, Hercules, CA, USA) in absorbance mode at a wavenumber range of $550-4000 \mathrm{~cm}^{-1}$ and resolution of $0.4 \mathrm{~cm}^{-1}$. Baseline corrected spectrum was used to identify the representative peaks of surface functional groups.

\subsection{Soil Collection and Preparation}

Soil samples were collected from the greenhouse experimental station of Kangwon National University, Chuncheon, Korea $\left(37^{\circ} 52^{\prime} 17^{\prime \prime} \mathrm{N}, 127^{\circ} 44^{\prime} 44^{\prime \prime} \mathrm{E}\right)$ from 0 to $25 \mathrm{~cm}$ depth. Air-dried soils were passed through a 2-mm sieve. Pipette method and USDA soil textural triangle were used to determine the soil texture [51]. The soil texture was sandy loam, and the particle size distribution in sand, silt, and clay was $58.18 \%, 30.16 \%$, and $11.66 \%$, respectively.

\subsection{Hydraulic Conductivity Experiment}

The BC500 ( $<2 \mathrm{~mm}$ particle size) was applied to $2 \mathrm{~mm}$ sieved soil at five rates of $0,2.5 \%, 5.0 \%$, $7.5 \%$, and $10 \%\left(\mathrm{w} \cdot \mathrm{w}^{-1}\right)$. Then it was completely mixed using a hand spade, and packed in soil cores ( $5 \mathrm{~cm}$ inside diameter by $5 \mathrm{~cm}$ height) to a constant height of $4 \mathrm{~cm}$ and an empty space of $1 \mathrm{~cm}$ with a mild compaction force. Soil cores were allowed to equilibrate for 30 days to study the effect of the short-term impact of BC500 on soil hydraulic properties in sandy loam soil. The bulk density of each soil core was determined separately using the oven-dried soil weight and volume. Then, all soil cores were slowly saturated from bottom to top with tap water in a water bath for four days so that all the pores were saturated with water. Each treatment was repeated three times.

Saturated soil cores were used to determine the saturated hydraulic conductivity $\left(\mathrm{K}_{\text {sat }}\right)$ using the falling-head method [52]. A graduated stand pipe having $1 \mathrm{~cm}$ diameter and $49 \mathrm{~cm}$ height of water head was used to retain the falling-head. The total height of the water head was $50 \mathrm{~cm}$, including the water height in the soil core. The time for head falling by $25 \mathrm{~cm}$ was recorded and the saturated hydraulic conductivity in each treatment was calculated (Equation (1)):

$$
\mathrm{K}_{\mathrm{sat}}=(d s / d c)^{2}(L / \Delta t) \ln \left(h_{2} / h_{1}\right)
$$

where $d s$ is the stand pipe diameter $(\mathrm{cm}), d c$ is the soil core diameter $(\mathrm{cm}), L$ is the soil height $(\mathrm{cm}), \Delta t$ is elapsed time (s), and $h_{1}$ and $h_{2}$ are the initial and final water heads, respectively.

Water holding capacity was also determined with the gravity flow method [53].

\subsection{Statistical Analysis}

The statistical analysis was done using the analysis of variance (ANOVA) with a Tukey's family comparison at 0.05 probability $(p)$ level [54]. To understand the relationship between application rate of BC500 and hydraulic properties, regression analysis (i.e., linear and nonlinear) and curve fitting was conducted. The Spearman correlation coefficients $\left(r_{s}\right)$ for BC500 addition rate versus $\mathrm{K}_{\text {sat }}$ or bulk density, and the Pearson correlation coefficients $\left(r_{p}\right)$ for the BC500 addition rate versus WHC were reported.

\section{Results and Discussion}

The $\mathrm{K}_{\text {sat }}$ were significantly affected by the biochar application rate $(p<0.0001)$, and had a strong negative correlation $\left(r_{s}=-0.98\right)$. Relative to the $\mathrm{K}_{\mathrm{sat}}$ of the control $\left(3.0 \times 10^{-4} \mathrm{~cm} \cdot \mathrm{s}^{-1}\right)$, the $2.5 \%$, $5 \%, 7.5 \%$ and $10 \%$ BC500 treatments reduced the $\mathrm{K}_{\text {sat }}$ by $46.6 \%, 63.4 \%, 76.7 \%$ and $83.5 \%$, respectively 
(Table 1). However, the $\mathrm{K}_{\text {sat }}$ of soils amended with $7.5 \%-10 \%$ BC500 were not significantly lower than that of soil amended with $5 \%$ BC500. The values of $\mathrm{K}_{\text {sat }}$ were well fit logarithmically to the increased BC500 application rate $\left(y=2.9943 \mathrm{e}^{-0.1989 x}, \mathrm{R}^{2}=0.98\right.$; Table 1).

Table 1. The changes of bulk density, water holding capacity (WHC), and saturated hydraulic conductivity $\left(\mathrm{K}_{\text {sat }}\right)$ after biochar was added at different rates to the sandy loam soil. (Mean \pm standard deviation; $n=3$.) $r_{\mathrm{p}}$ is the Pearson correlation coefficient; $r_{\mathrm{s}}$ is the Spearman correlation coefficient. Different letters represent the significant difference at $p<0.05$.

\begin{tabular}{|c|c|c|c|}
\hline $\begin{array}{c}\text { Biochar Application Rate } \\
\left(\% \mathbf{w} \cdot \mathbf{w}^{-1}\right)\end{array}$ & Bulk Density $\left(\mathrm{g} \cdot \mathrm{cm}^{-3}\right)$ & WHC (\%) & $\mathrm{K}_{\text {sat }}\left(\times 10^{-4} \mathrm{~cm} \cdot \mathrm{s}^{-1}\right)$ \\
\hline 0 & $1.26 \pm 0.03 \mathrm{a}$ & $30.13 \pm 1.90 \mathrm{c}$ & $3.09 \pm 0.00 \mathrm{a}$ \\
\hline 2.5 & $1.24 \pm 0.01 \mathrm{ab}$ & $36.97 \pm 1.04 \mathrm{~b}$ & $1.65 \pm 0.00 \mathrm{~b}$ \\
\hline 5.0 & $1.21 \pm 0.00 \mathrm{~b}$ & $35.65 \pm 1.10 \mathrm{bc}$ & $1.13 \pm 0.00 \mathrm{cb}$ \\
\hline 7.5 & $1.15 \pm 0.02 \mathrm{c}$ & $39.64 \pm 1.58 \mathrm{ab}$ & $0.72 \pm 0.00 \mathrm{c}$ \\
\hline 10 & $1.01 \pm 0.01 \mathrm{~d}$ & $43.31 \pm 3.72 \mathrm{a}$ & $0.51 \pm 0.00 \mathrm{c}$ \\
\hline Best fit curve & $\begin{array}{c}y=-0.003 x^{2}+0.0058 x+1.2551 \\
R^{2}=0.99\end{array}$ & $\begin{array}{l}y=1.161 x+31.33 \\
R^{2}=0.88\end{array}$ & $\begin{array}{c}y=2.9943 e^{-0.1989 x} \\
R^{2}=0.99\end{array}$ \\
\hline \multicolumn{4}{|c|}{ Correlation statistics to biochar application rate } \\
\hline & $r_{\mathrm{p}}=-0.92 ; p<0.0001$ & $r_{\mathrm{p}}=0.87 ; p<0.0001$ & $r_{\mathrm{s}}=-0.98 ; p<0.0001$ \\
\hline
\end{tabular}

Soil hydraulic conductivity primarily governs the soil water movement and retention [55]. Compared to other soil textures (i.e., clayey and silty), sandy soils (e.g., sandy loam) exhibit fairly high downward water movement. Sandy loam soil reported reductions in $\mathrm{K}_{\text {sat }}$ following the BC500 application [56,57]. Increased soil microporosity (i.e., $<2 \mathrm{~nm}$ ) might be the main cause of reduced hydraulic conductivity in sandy loam soil treated with biochar, as it has huge surface area and pore volume [42,58]. Barnes et al. [47] observed a 92\% reduction in $\mathrm{K}_{\text {sat }}$ following the biochar treatment in a sandy soil. They observed a reduction of bulk density by $17.75 \%$ (i.e., 1.69 to $1.39 \mathrm{~g} \cdot \mathrm{cm}^{-3}$ ) due to the higher porosity of incorporated biochar (0.62) than that of sandy soil (0.17-0.33). The highly porous structure of biochar constructs two theoretical capillary flow paths in the biochar-soil matrix: (1) in between biochar and soil; and (2) connecting the pores within the biochar [58,59]. In the current study, both of these capillaries could possibly have reduced $\mathrm{K}_{\text {sat }}$ in the sandy loam soil via the reduced diameter of the water movement pathways. Moreover, soil macropores in the sandy loam soil could be clogged with soft biochar particles, thereby reducing the pore radii [47].

The WHC of the BC500 treated soils had a reciprocal relationship with its $\mathrm{K}_{\text {sat }}$ (Table 1). The addition of $\mathrm{BC} 500$ improved the soil $\mathrm{WHC} \%$ at a rate of 1.16 per $\Delta t \mathrm{BC} 500 \%$. The increased BC500 application rate showed a positive correlation $\left(r_{p}=0.87 ; p<0.0001\right)$ to the WHC in tested soil. This could be attributed to the water retention ability of the porous structure of the BC500.

Soil water availability has been known to increase with increasing WHC in soils [60]. Nelissen et al. [8] reported enhanced WHC in sandy loam soil in response to biochar incorporation. The biochar incorporation increases the WHC due to the reduction of bulk density and the enhancement of porosity in soils. In the long term, biochar acts as a binding material to form stable microaggregates $[8,61]$. These microaggregates facilitate the formation of capillaries in the soil system [62] and thereby increase the water retention [63].

The bulk density in the selected soil is in the margin for the optimal plant root development and soil water retention [64]. Soil bulk density was continually reduced by the increasing application rate of BC500 ( $y=-0.023 x+1.292, R^{2}=0.868$; Table 1$)$. Soil bulk density is a highly dynamic factor due to both natural and anthropogenic processes and has a direct relationship with the soil water movement and WHC [65]. Management of soil bulk density level is essential for optimal water retention in soil [66]. The reduced particle density and enhanced porosity in the soil system could be due to the reduction in soil bulk density consequent to the application of low-density and porous BC500 [8,40,67,68].

Particle size distribution of BC500 showed a higher amount of sand-size particles (58\%) than clay-size particles $(0.06 \%)$ (Figure 1$)$. The biochar was described as a porous aggregate, as discussed 
previously [69]. These micropores contained in BC500 particles would have increased the WHC, and reduced the $\mathrm{K}_{\mathrm{sat}}$ in sandy loam soil. The pore size distribution curve calculated from BET analysis illustrated that $\mathrm{BC} 500$ have hierarchical micro/mesoporous textures, and characteristic small pore volume at the pore diameter of $>2.1 \mathrm{~nm}$ (micropores), and two distinct peaks in the smaller pore diameter range (Figure 2). Therefore, BC500 contained a higher percentage of micropores compared to mesopores. These porous structures helped retain water in the soil matrix. The SEM images clearly visualized the pore arrangement on the biochar surface (Figure 3a,b), and identified micropores in BET analysis that might have been located inside the biochar particles.

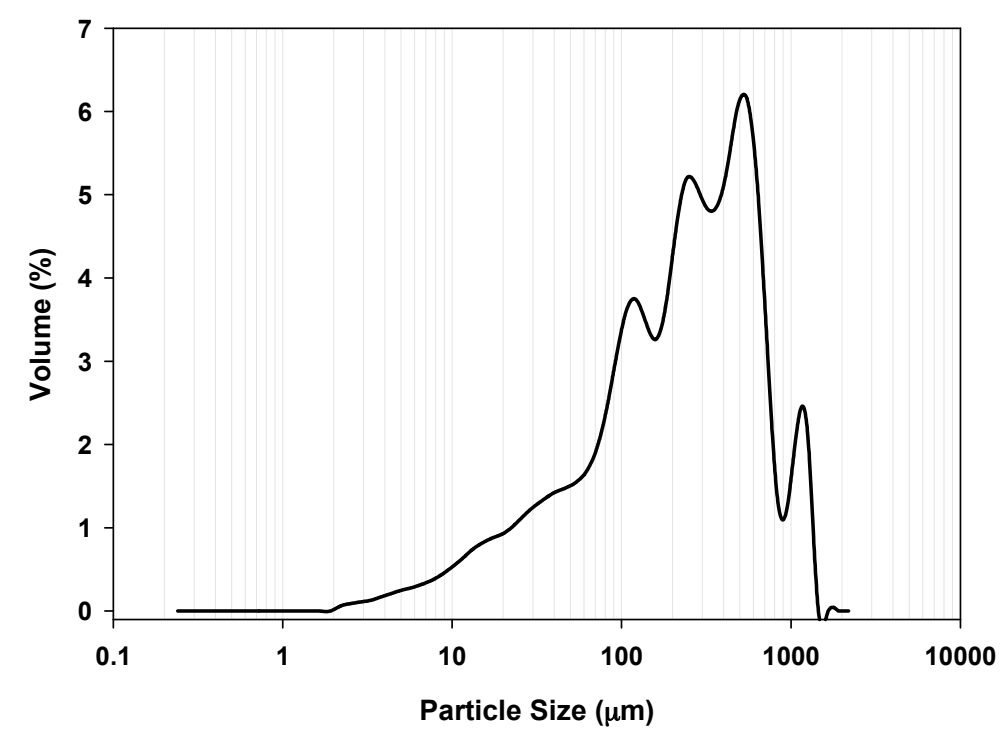

Figure 1. Particle size distribution of $2 \mathrm{~mm}$ sieved corn residue biochar produced at $500{ }^{\circ} \mathrm{C}$.

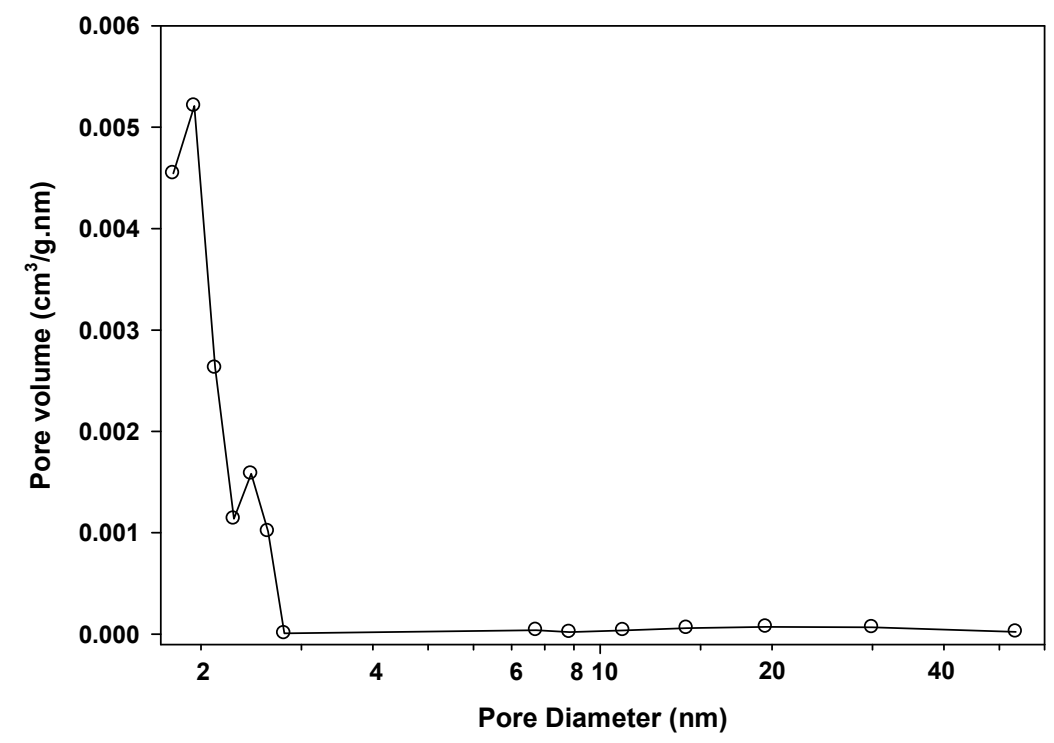

Figure 2. Pore size distribution of corn residue biochar produced at $500{ }^{\circ} \mathrm{C}$.

The surface characterization of BC500 illustrated that BC500 surface does not consist of hydrophobic functional groups (Figure 4). The spectral area of $2800-3000 \mathrm{~cm}^{-1}$ is strongly associated with the hydrophobic functional groups such as $-\mathrm{C}-\mathrm{H}$ stretches of alkyl groups [70]. The affinity of biochar surface to water depends on the hydrophilic or hydrophobic properties of its surface. Hydrophilic surface of biochar helps to retain water in the biochar-soil matrix for a considerable time. 
The hydrophilic surface exerts positive capillary pressure due to its $<90^{\circ}$ contact angle and helps water enter the pores, while hydrophobic surfaces behave oppositely to prevent water from entering pores. The water affinity of biochar is influenced by its surface area, pore volume, and aliphatic functional groups [38], and those properties vary with the pyrolysis condition and type of biomass [71]. However, Das and Sarmah [71] observed that hydrophobic biochar surfaces could be converted into hydrophilic surfaces when exposed to water. Moreover, biochar produced at high temperatures $\left(\geq 500{ }^{\circ} \mathrm{C}\right)$ is more hydrophilic than that at low temperatures mainly because of the removal of aliphatic functional groups [38]. The biochar produced at high temperatures possesses pores unclogged by volatile/mobile matter and converts the biochar surface to be more hydrophilic [71]. However, Jeffery et al. [72] reported no significant impact on soil water retention and $\mathrm{K}_{\text {sat }}$ after the application of hay biochar produced at 400 and $600{ }^{\circ} \mathrm{C}$ to sandy soil.
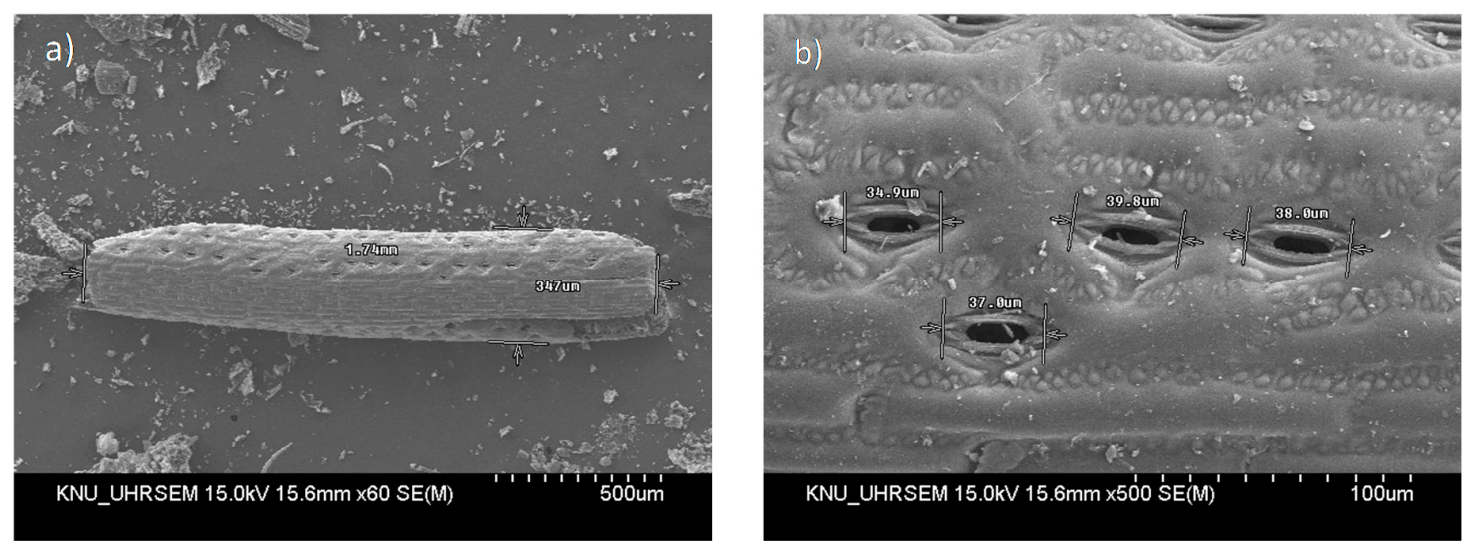

Figure 3. Scanning electron micrographs: the biochar particle size that showed the highest frequency and pore distribution on its surface (a); size of the pores on biochar surface (b).

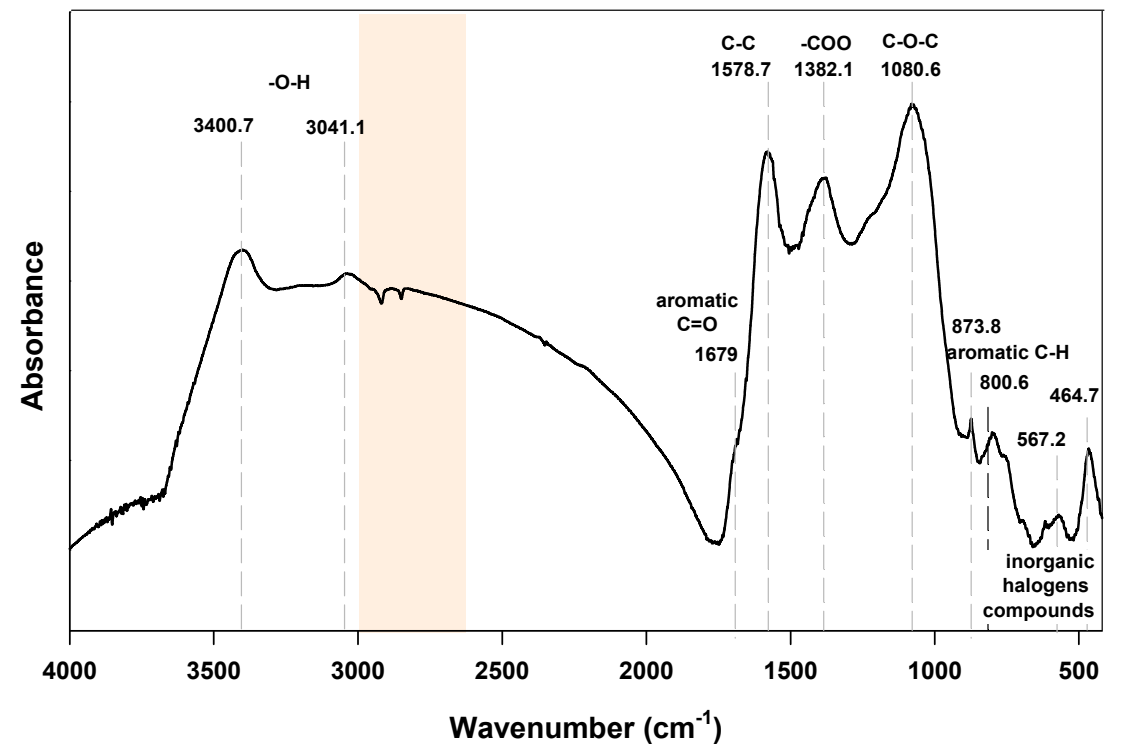

Figure 4. FTIR spectrum of corn residue biochar produced at $500{ }^{\circ} \mathrm{C}$. Shaded area represents the hydrophobic wavenumbers.

\section{Conclusions}

BC500 showed positive impacts on the hydraulic properties of sandy loam soil. The promising reduction in $\mathrm{K}_{\mathrm{sat}}$ to a desirable level for plant growth could be obtained in sandy loam soil following the application of $\mathrm{BC} 500$. However, $\mathrm{K}_{\text {sat }}$ did not continue to decrease significantly past a certain level 
of BC500 application rate (i.e., $5 \%$ ). Enhanced soil porosity with a high amount of micropores must be the main reason for the reduced hydraulic conductivity and enhanced water retention in sandy loam soil. The BC500 particles that contain a huge amount of micropores would have played the main role in increasing the micropores in the soil matrix. Moreover, decreases in soil bulk density by increasing organic carbon additions affects the soil's hydraulic properties and causes it to retain more water. Hence, without any uncertainty BC500 could be used to enhance the soil hydraulic properties in sandy loam soil. The biochar surface hydrophobicity analysis might also be important in biochar application for soil hydraulic property improvements. According to the study results, the $\mathrm{K}_{\text {sat }}$ reduction is maximized at the 5\% application rate of BC500 and further loading of BC500 might not be useful to reduce the $\mathrm{K}_{\mathrm{sat}}$. However, further laboratory and field studies are needed to find the optimum rate of BC500 application. Then, prior to field application, in situ evaluation of hydraulic properties is imperative for soil management using BC500 as an amendment. Furthermore, a single dose of biochar application might be offered to have a long-term effect on soil hydraulic properties due to the comparatively high stability of biochar in soil compared to other organic amendments (e.g., plant residues, composts, manure) [73]. Therefore, BC500 would have the potential to reduce irrigation costs in sandy loam soils.

Acknowledgments: This research is supported by a 2015 Research Grant from Kangwon National University (No. 520150101), the Korea Ministry of Environment, as a Geo-Advanced Innovative Action Project (G112-00056-0004-0), and the National Research Foundation of Korea Grant funded by the Korean Government [grant number NRF-2016R1C1B2006336]. Instrumental analyses were supported by the Korea Basic Science Institute, the Environmental Research Institute, and the Central Laboratory of Kangwon National University, Korea.

Author Contributions: Avanthi Deshani Igalavithana and Yong Sik Ok carried out the experiment and drafted the manuscript under the supervision of Sang Soo Lee. Nabeel Khan Niazi, Muhammad Rizwan, Mohammad I. Al-Wabel, Adel R. A. Usman, and Deok Hyun Moon helped draft the manuscript and reviewed the manuscript. All authors read and approved the final manuscript.

Conflicts of Interest: The authors declare no conflict of interest.

\section{References}

1. Lai, J.; Ren, L. Estimation of effective hydraulic parameters in heterogeneous soils at field scale. Geoderma 2016, 264, 28-41. [CrossRef]

2. Badorreck, A.; Gerke, H.H.; Hüttl, R.F. Effects of Ground-Dwelling Beetle Burrows on Infiltration Patterns and Pore Structure of Initial Soil Surfaces. Vadose Zone J. 2012, 11, doi-10. [CrossRef]

3. Carmell, R.Q. Reduced tillage in north-west Europe-A review. Soil Tillage Res. 1985, 5, 129-177.

4. Cui, K.; Défossez, P.; Cui, Y.J.; Richard, G. Soil compaction by wheeling: changes in soil suction caused by compression. Eur. J. Soil Sci. 2010, 61, 599-608. [CrossRef]

5. Singh, K.; Mishra, A.K.; Singh, B.; Singh, R.P.; Patra, D.D. Tillage Effects on Crop Yield and Physicochemical Properties of Sodic Soils. Land Degrad. Dev. 2016, 27, 223-230. [CrossRef]

6. Alaoui, A.; Lipiec, J.; Gerke, H.H. A review of the changes in the soil pore system due to soil deformation: A hydrodynamic perspective. Soil Tillage Res. 2011, 115-116, 1-15. [CrossRef]

7. Nimmo, J.R. Porosity and Pore Size Distribution. In Encyclopedia of Soils in the Environment; Hillel, D., Ed.; Elsevier: London, UK, 2004; pp. 295-303.

8. Nelissen, V.; Ruysschaert, G.; MankáAbusi, D.; D’Hose, T.; de Beuf, K.; Al-Barri, B.; Cornelis, W.; Boeckx, P. Impact of a woody biochar on properties of a sandy loam soil and spring barley during a two-year field experiment. Eur. J. Agron. 2015, 62, 65-78. [CrossRef]

9. Wessolek, G.; Plagge, R.; Leij, F.J.; van Genuchten, M.T. Analysing problems in describing field and laboratory measured soil hydraulic properties. Geoderma 1994, 64, 93-110. [CrossRef]

10. Beerten, K.; Deforce, K.; Mallants, D. Landscape evolution and changes in soil hydraulic properties at the decadal, centennial and millennial scale: A case study from the Campine area, northern Belgium. Catena 2012, 95, 73-84. [CrossRef]

11. Sadeghi, M.; Tuller, M.; Gohardoust, M.R.; Jones, S.B. Column-scale unsaturated hydraulic conductivity estimates in coarse-textured homogeneous and layered soils derived under steady-state evaporation from a water table. J. Hydrol. 2014, 519, 1238-1248. [CrossRef] 
12. Neyshabouri, M.R.; Rahmati, M.; Doussan, C.; Behroozinezhad, B. Simplified estimation of unsaturated soil hydraulic conductivity using bulk electrical conductivity and particle size distribution. Soil Res. 2013, 51, 23-33. [CrossRef]

13. Shanmugam, S.; Abbott, L.K.; Murphy, D.V. Clay addition to lime-amended biosolids overcomes water repellence and provides nitrogen supply in an acid sandy soil. Biol. Fertil. Soils 2014, 50, 1047-1059. [CrossRef]

14. Zhang, S.; Grip, H.; Lövdahl, L. Effect of soil compaction on hydraulic properties of two loess soils in China. Soil Tillage Res. 2006, 90, 117-125. [CrossRef]

15. Zhao, Y.; Peth, S.; Horn, R.; Krümmelbein, J.; Ketzer, B.; Gao, Y.; Doerner, J.; Bernhofer, C.; Peng, X. Modeling grazing effects on coupled water and heat fluxes in Inner Mongolia grassland. Soil Tillage Res. 2010, 109, 75-86. [CrossRef]

16. Ahmad, M.; Lee, S.S.; Rajapaksha, A.U.; Vithanage, M.; Zhang, M.; Cho, J.S.; Lee, S.E.; Ok, Y.S. Trichloroethylene adsorption by pine needle biochars produced at various pyrolysis temperatures. Bioresour. Technol. 2013, 143, 615-622. [CrossRef] [PubMed]

17. Ahmad, M.; Rajapaksha, A.U.; Lim, J.E.; Zhang, M.; Bolan, N.; Mohan, D.; Vithanage, M.; Lee, S.S.; Ok, Y.S. Biochar as a sorbent for contaminant management in soil and water: A review. Chemosphere 2014, 99, 19-33. [CrossRef] [PubMed]

18. Case, S.D. C.; McNamara, N.P.; Reay, D.S.; Stott, A.W.; Grant, H.K.; Whitaker, J. Biochar suppresses $\mathrm{N}_{2} \mathrm{O}$ emissions while maintaining N availability in a sandy loam soil. Soil Biol. Biochem. 2015, 81, 178-185. [CrossRef]

19. Lee, S.S.; Shah, S.H.; Awad, Y.M.; Kumar, S.; Ok, Y.S. Synergy effects of biochar and polyacrylamide on plants growth and soil erosion control. Environ. Earth Sci. 2015, 74, 2463-2473. [CrossRef]

20. Ok, Y.S.; Chang, S.X.; Gao, B.; Chung, H.J. SMART biochar technology-A shifting paradigm towards advanced materials and healthcare research. Environ. Technol. Innov. 2015, 4, 206-209. [CrossRef]

21. Igalavithana, A.D.; Ok, Y.S.; Usman, A.R.A.; Al-Wabel, M.I.; Oleszczuk, P.; Lee, S.S. The Effects of Biochar Amendment on Soil Fertility. In Agricultural and Environmental Applications of Biochar: Advances and Barriers; Guo, M., He, Z., Uchimiya, M., Eds.; SSSA Special Publication 63; Soil Science Society of America, Inc.: Madison, WI, USA, 2016; pp. 123-144.

22. Singh, B.; Singh, B.P.; Cowie, A.L. Characterization and evaluation of biochars for their application as a soil amendment. Soil Res. 2010, 48, 516-525. [CrossRef]

23. Rajapaksha, A.U.; Chen, S.S.; Tsang, D.C.W.; Zhang, M.; Vithanage, M.; Mandal, S.; Gao, B.; Bolan, N.S.; Ok, Y.S. Engineered/designer biochar for contaminant removal/immobilization from soil and water: Potential and implication of biochar modification. Chemosphere 2016, 148, 276-291. [CrossRef] [PubMed]

24. Lehmann, J.; da Silva, J.P.; Steiner, C.; Nehls, T.; Zech, W.; Glaser, B. Nutrient availability and leaching in an archaeological Anthrosol and a Ferralsol of the Central Amazon basin: fertilizer, manure and charcoal amendments. Plant Soil 2003, 249, 343-357. [CrossRef]

25. Park, J.H.; Ok, Y.S.; Kim, S.H.; Kang, S.W.; Cho, J.S.; Heo, J.S.; Delaune, R.D.; Seo, D.C. Characteristics of biochars derived from fruit tree pruning wastes and their effects on lead adsorption. J. Korean Soc. Appl. Biol. Chem. 2015, 58, 751-760. [CrossRef]

26. Rajapaksha, A.U.; Ahmad, M.; Vithanage, M.; Kim, K.R.; Chang, J.Y.; Lee, S.S.; Ok, Y.S. The role of biochar, natural iron oxides, and nanomaterials as soil amendments for immobilizing metals in shooting range soil. Environ. Geochem. Health 2015, 37, 931-942. [CrossRef] [PubMed]

27. Rizwan, M.; Ali, S.; Qayyum, M.F.; Ibrahim, M.; Rehman, M.Z.; Abbas, T.; Ok, Y.S. Mechanisms of biochar-mediated alleviation of toxicity of trace elements in plants: A critical review. Environ. Sci. Pollut. Res. 2016, 23, 2230-2248. [CrossRef] [PubMed]

28. Kammann, C.I.; Linsel, S.; Gößling, J.W.; Koyro, H.W. Influence of biochar on drought tolerance of Chenopodium quinoa Willd and on soil-plant relations. Plant Soil 2011, 345, 195-210. [CrossRef]

29. Baronti, S.; Vaccari, F.P.; Miglietta, F.; Calzolari, C.; Lugato, E.; Orlandinie, S.; Pinid, R.; Zulianf, C.; Genesio, L. Impact of biochar application on plant water relations in Vitis vinifera (L.). Eur. J. Agron. 2014, 53, 38-44. [CrossRef]

30. Bruun, E.W.; Petersen, C.T.; Hansen, E.; Holm, J.K.; Hauggaard-Nielsen, H. Biochar amendment to coarse sandy subsoil improves root growth and increases water retention. Soil Use Manag. 2014, 30, 109-118. [CrossRef]

31. Liu, C.; Wang, H.; Tang, X.; Guan, Z.; Reid, B.J.; Rajapaksha, A.U.; Ok, Y.S.; Sun, H. Biochar increased water holding capacity but accelerated organic carbon leaching from a sloping farmland soil in China. Environ. Sci. Pollut. Res. 2016, 23, 995-1006. [CrossRef] [PubMed] 
32. Oguntunde, P.G.; Abiodun, B.J.; Ajayi, A.E.; van de Giesen, N. Effects of charcoal production on soil physical properties in Ghana. J. Plant Nutr. Soil Sci. 2008, 171, 591-596. [CrossRef]

33. Deveraux, R.C.; Sturrock, C.J.; Mooney, S.J. The effects of biochar on soil physical properties and winter wheat growth. Earth Environ. Sci. Trans. R. Soc. Edinb. 2012, 103, 13-18.

34. Rinklebe, J.; Shaheen, S.M.; Frohne, T. Amendment of biochar reduces the release of toxic elements under dynamic redox conditions in a contaminated floodplain soil. Chemosphere 2016, 142, 41-47. [CrossRef] [PubMed]

35. Atkinson, C.J.; Fitzgerald, J.D.; Hipps, N.A. Potential mechanisms for achieving agricultural benefits from biochar application to temperate soils: A review. Plant Soil 2010, 337, 1-18. [CrossRef]

36. Major, J.; Lehmann, J.; Rondon, M.; Goodale, C.L. Fate of soil-applied black carbon: downward migration, leaching and soil respiration. Glob. Chang. Biol. 2010, 16, 1366-1379. [CrossRef]

37. Awad, Y.M.; Blagodatskaya, E.; Ok, Y.S.; Kuzyakov, Y. Effects of polyacrylamide, biopolymer and biochar on the decomposition of ${ }^{14} \mathrm{C}$-labelled maize residues and on their stabilization in soil aggregates. Eur. J. Soil Sci. 2013, 64, 488-499. [CrossRef]

38. Gray, M.; Johnson, M.G.; Dragila, M.I.; Kleber, M. Water uptake in biochars: The roles of porosity and Hydrophobicity. Biomass Bioenergy 2014, 61, 196-205. [CrossRef]

39. Rouquerol, J.; Avnir, D.; Fairbridge, C.W.; Everett, D.H.; Haynes, J.M.; Pernicone, N.; Ramsay, J.D.F.; Sing, K.S.W.; Unger, K.K. Recommendations for the characterization of porous solids (Technical Report). Pure Appl. Chem. 1994, 66, 1739-1758. [CrossRef]

40. Downie, A.; Crosky, A.; Munroe, P. Physical properties of biochar. In Biochar for Environmental Management: Science and Technology; Lehmann, J., Joseph, S., Eds.; Earthscan: London, UK, 2009; pp. 13-32. Available online: https://books.google.co.kr/books?id=w-CUty_JIfcC\&printsec=frontcover\&source=gbs_ ge_summary_r\&cad=0\#v=onepage \&q\&f=false (accessed on 2 January 2017).

41. Jeffery, S.; Verheijen, F.G.A.; van der Velde, M.; Bastos, A.C. A quantitative review of the effects of biochar application to soils on crop productivity using meta-analysis. Agric. Ecosyst. Environ. 2011, 144, $175-187$. [CrossRef]

42. Glaser, B.; Lehmann, J.; Zech, W. Ameliorating physical and chemical properties of highly weathered soils in the tropics with charcoal: A review. Biol. Fertil. Soils 2002, 35, 219-230. [CrossRef]

43. Chan, K.Y.; Van Zwieten, L.; Meszaros, J.; Downie, A.; Joseph, S. Agronomic values of green waste biochar as a soil amendment. Soil Res. 2007, 45, 629-634. [CrossRef]

44. Kammann, C.; Ratering, S.; Eckhard, C.; Müller, C. Biochar and Hydrochar Effects On Greenhouse Gas (Carbon Dioxide, Nitrous Oxide, and Methane) Fluxes from Soils. J. Environ. Qual. 2012, 41, 1052-1066. [CrossRef] [PubMed]

45. Novak, J.M.; Busscher, W.J.; Watts, D.W.; Amonette, J.E.; Ippolito, J.A.; Lima, I.M.; Gaskin, J.; Das, K.C.; Steiner, C.; Ahmedna, M.; et al. Biochars Impact on Soil-Moisture Storage in an Ultisol and Two Aridisols. Soil Sci. 2012, 177, 310-320. [CrossRef]

46. Zhang, A.; Bian, R.; Pan, G.; Cui, L.; Hussain, Q.; Li, L.; Zheng, J.; Zhang, X.; Han, X.; Yu, X. Effects of biochar amendment on soil quality, crop yield and greenhouse gas emission in Chinese rice paddy: A field study of 2 consecutive rice growing cycles. Field Crops Res. 2012, 127, 153-160. [CrossRef]

47. Barnes, R.T.; Gallagher, M.E.; Masiello, C.A.; Liu, Z.; Dugan, B. Biochar-Induced Changes in Soil Hydraulic Conductivity and Dissolved Nutrient Fluxes Constrained by Laboratory Experiments. PLoS ONE 2014, 9 , 0108340. [CrossRef] [PubMed]

48. Karhu, K.; Mattila, T.; Bergström, I.; Regina, K. Biochar addition to agricultural soil increased $\mathrm{CH}_{4}$ uptake and water holding capacity-Results from a short-term pilot field study. Agric. Ecosyst. Environ. 2011, 140, 309-313. [CrossRef]

49. Case, S.D.C.; McNamara, N.P.; Reay, D.S.; Whitaker, J. Can biochar reduce soil greenhouse gas emissions from a Miscanthus bioenergy crop? Glob. Chang. Biol. Bioenergy 2013, 6, 76-89. [CrossRef]

50. Tammeorg, P.; Simojoki, A.; Mäkelä, P.; Stoddard, F.L.; Alakukku, L.; Helenius, J. Biochar application to a fertile sandy clay loam in boreal conditions: Effects on soil properties and yield formation of wheat, turnip rape and faba bean. Plant Soil 2014, 374, 89-107. [CrossRef]

51. Gee, G.W.; Bauder, J.W. Particle-size analysis. In Methods of Soil Analysis: Part 1 Physical and Mineralogical Methods, 2nd ed.; Klute, A., Ed.; Soil Science Society of America: Madison, WI, USA, 1986; pp. 383-411. Available online: https://dl.sciencesocieties.org/publications/books/tocs/sssabookseries/ methodsofsoilan1 (accessed on 26 November 2016). 
52. Klute, A.; Dirksen, D.C. Hydraulic conductivity and diffusivity: Laboratory methods. In Methods of Soil Analysis: Part 1, Agronomy Monogram, 2nd ed.; Klute, A., Ed.; America Society of Agronomy: Madison, WI, USA, 1986; pp. 687-734. Available online: https://www.cabdirect.org/cabdirect/abstract/19881917612 (accessed on 26 November 2016).

53. Haney, R.L.; Haney, E.B. Simple and Rapid Laboratory Method for Rewetting Dry Soil for Incubations. Commun. Soil Sci. Plan 2010, 4, 1493-1501. [CrossRef]

54. $S A S^{\circledR} 9.3$ Procedures Guide Statistical Procedures; SAS Institute Inc.: Cary, NC, USA, 2013. Available online: https://support.sas.com/documentation/onlinedoc/base/procstat93m1.pdf (accessed on 26 November 2016).

55. Bodner, G.; Scholl, P.; Loiskandl, W.; Kaul, H.P. Environmental and management influences on temporal variability of near saturated soil hydraulic properties. Geoderma 2013, 204-205, 120-129. [CrossRef] [PubMed]

56. Lichner, L.; Hallett, P.D.; Drongová, Z.; Czachor, H.; Kovacik, L.; Mataix-Solera, J.; Homolák, M. Algae influence the hydrophysical parameters of a sandy soil. Catena 2013, 108, 58-68. [CrossRef]

57. Ibrahim, H.M.; Al-Wabel, M.I.; Usman, A.R.A.; Al-Omran, A. Effect of Conocarpus Biochar Application on the Hydraulic Properties of a Sandy Loam Soil. Soil Sci. 2013, 178, 165-173. [CrossRef]

58. Sun, H.; Hockaday, W.C.; Masiello, C.A.; Zygourakis, K. Multiple Controls on the Chemical and Physical Structure of Biochars. Ind. Eng. Chem. Res. 2012, 51, 3587-3597. [CrossRef]

59. Brewer, C.E.; Chuang, V.J.; Masiello, C.A.; Gonnermann, H.; Gao, X.; Dugan, B.; Driver, L.E.; Panzacchi, P.; Zygourakis, K.; Davies, C.A. New approaches to measuring biochar density and porosity. Biomass Bioenergy 2014, 66, 176-185. [CrossRef]

60. De Michele, C.; Vezzoli, R.; Pavlopoulos, H.; Scholes, R.J. A minimal model of soil water-vegetation interactions forced by stochastic rainfall in water-limited ecosystems. Ecol. Model. 2008, 212, 397-407. [CrossRef]

61. Brodowski, S.; John, B.; Flessa, H.; Amelung, W. Aggregate-occluded black carbon in soil. Eur. J. Soil Sci. 2006, 57, 539-546. [CrossRef]

62. Rabbi, S.; Wilson, B.R.; Lockwood, P.V.; Daniel, H.; Young, I.M. Aggregate hierarchy and carbon mineralization in two Oxisols of New South Wales, Australia. Soil Tillage Res. 2015, 146, 193-203. [CrossRef]

63. Blanco-Canqui, H.; Lal, R. Corn stover removal impacts on micro-scale soil physical properties. Geoderma 2008, 145, 335-346. [CrossRef]

64. NRCS USDA. Soil Bulk Density/Moisture/Aeration, Soil Quality Kit-Guides for Educators. 2011. Available online: http://www.nrcs.usda.gov/Internet/FSE_DOCUMENTS/nrcs142p2_053260.pdf (accessed on 26 November 2016).

65. Ahmad, W.; Khan, F.; Naeem, M. Improvement in physical properties of eroded agricultural soils through agronomic management practices. Indian J. Agric. Sci. 2014, 84, 850-855.

66. Safadoust, A.; Feizee, P.; Mahboubi, A.A.; Gharabaghi, B.; Mosaddeghi, M.R.; Ahrens, B. Least limiting water range as affected by soil texture and cropping system. Agric. Water Manag. 2014, 136, 34-41. [CrossRef]

67. Gupta, S.C.; Larson, W.E. Estimating soil water retention characteristics from particle size distribution, organic matter percent, and bulk density. Water Resour. Res. 1979, 15, 1633-1635. [CrossRef]

68. Githinji, L. Effect of biochar application rate on soil physical and hydraulic properties of a sandy loam. Arch. Agron. Soil Sci. 2014, 60, 457-470. [CrossRef]

69. Lehmann, J.; Rillig, M.C.; Thies, J.; Masiello, C.A.; Hockaday, W.C.; Crowley, D. Biochar effects on soil biota-A review. Soil Biol. Biochem. 2011, 43, 1812-1836. [CrossRef]

70. Kinney, T.J.; Masiello, C.A.; Dugan, B.; Hockaday, W.C.; Dean, M.R.; Zygourakis, K.; Barnes, R.T. Hydrologic properties of biochars produced at different temperatures. Biomass Bioenergy 2012, 41, 34-43. [CrossRef]

71. Das, O.; Sarmah, A.K. Mechanism of waste biomass pyrolysis: Effect of physical and chemical pre-treatments. Sci. Total Environ. 2015, 537, 323-334. [CrossRef] [PubMed]

72. Jeffery, S.; Meinders, M.B.J.; Stoof, C.R.; Bezemer, T.M.; van de Voorde, T.F.; Mommer, L.; van Groenigen, J.W. Biochar application does not improve the soil hydrological function of a sandy soil. Geoderma 2015, 251-252, 47-54. [CrossRef]

73. Kuzyakove, Y.; Bogamolova, I.; Glaser, B. Biochar stability in soil: Decomposition during eight years and transformation as assessed by compound-specific ${ }^{14} \mathrm{C}$ analysis. Soil Biol. Biochem. 2014, 70, 229-236. [CrossRef]

(C) 2017 by the authors; licensee MDPI, Basel, Switzerland. This article is an open access article distributed under the terms and conditions of the Creative Commons Attribution (CC BY) license (http:/ / creativecommons.org/licenses/by/4.0/). 